\title{
Effect of Exhaust Gas Recirculation and Isobutanol Additive on Biodiesel Fuelled Diesel Engine for the Reduction of $\mathrm{NO}_{\mathrm{x}}$ Emissions
}

\author{
S. Kirankumar ${ }^{1}$, K. Apparao ${ }^{2}$ and R. Nagendrababu ${ }^{3}$ \\ ${ }^{1}$ Lecturer, Department of Mechanical Engineering, Bule Hora University, \\ Ethiopia \\ ${ }^{2}$ Professor, Hod, Deaprtment of Mechanical Engineering, Lakkireddy Ballireddy \\ College of Engineering, Mylavaram, Krishna(D.t), A.P., India \\ ${ }^{3}$ Professors, Principal, Sree Vahini Institute of Science and Technology, Tiruvuru, \\ Krishna (D.t), A.P., India \\ ${ }^{1}$ kirankumar.sureddy@gmail.com
}

\begin{abstract}
Cetane helps to reduce the ignition delay, which in turn reduces the combustion temperatures thereby reduce $N O_{x}$ emissions. Exhaust gas recirculation (EGR) proved to be an effective way to reduce the $\mathrm{NO}_{x}$ emissions. In this present experimental work, a combination of exhaust gas recirculation and cetane improver Isobutanol is used to investigate the performance and exhaust emissions of a single cylinder four stroke naturally aspirated direct injection and air cooled diesel engine. Test results shown that the brake thermal efficiency increases with the increase in the percentage of EGR which is accompanied by a reduction in brake specific fuel consumption and exhaust gas temperatures, and that biodiesel with cetane improver under 20\%EGR reduces $N O_{X}$ emissions by $33 \%$ when compared to baseline fuel without EGR. However carbon monoxide (CO), hydro carbon (HC) and smoke emissions increased with an increase in percentage of EGR.
\end{abstract}

Keywords: additive, exhaust gas recirculation (EGR), emissions, Isobutanol, performance

\section{Introduction}

The use of biodiesel necessitates the $\mathrm{NO}_{\mathrm{x}}$ reduction techniques like exhaust gas recirculation which is recirculation of a part of the exhaust gas into the intake which helps in reducing the $\mathrm{NO}_{\mathrm{x}}$ [1]. Oxygen content in biodiesel is the primary source for $\mathrm{NO}_{\mathrm{x}}$ to increase as nitrogen has a tendency to react with oxygen at higher temperatures in the combustion chamber and increases $\mathrm{NO}_{x}$ [2-3]. Diesel and bio-diesel blends require additives for improving the lubricant, ignition and better mixing. Oxygenates are promising for reducing particulates significantly since they contain oxygen content which aids in better combustion and lower exhaust emissions with a trade off between particulates and $\mathrm{NO}_{\mathrm{x}}$ [4-5]. This can be addressed by using the additives in modified engines like thermal barrier coated (TBC) engines. Additives in TBC engines exhibited improve efficiency, in addition to the reduction in $\mathrm{NO}_{\mathrm{x}}$ and maximum heat release rate. TBC direct injection diesel engine with fuel additives reduces the smoke density and $\mathrm{NO}_{\mathrm{x}}$ emission of the engine exhaust [6]. 1-4 dioxin, as an additive in TBC engines reduces smoke density with slight increase in brake thermal efficiency and $\mathrm{NO}_{\mathrm{x}}$ with a drop in fuel economy [7]. Reduced ignition delay reduces combustion temperature which aids in reducing $\mathrm{NO}_{\mathrm{x}}$ emissions since higher combustion temperature is the primary source for $\mathrm{NO}_{\mathrm{x}}$ to increase [8]. The use of cetane improvers is an alternative way to reduce the $\mathrm{NO}_{\mathrm{x}}$ 
emissions which can be done by reducing ignition delay in diesel engines [9]. Cetane improver with oxygenate such as glycol ether reduces particulate, hydro carbon (HC), and carbon monoxide (CO) emissions [10]. Ethanol-diesel blends with EHN as additive increase $\mathrm{BTE}$ and reduce significantly the emissions like $\mathrm{CO}, \mathrm{HC}$, smoke, and particulates in common rail direct injection (CRDI) diesel engine and decrease cylinder pressure, ignition delay, the maximum rate of pressure rise, and the combustion noise [11]. Ethanol-diesel blends with cetane improver with advanced fuel injection angle show a large decrease in exhaust smoke concentration and a small decrease in exhaust $\mathrm{NO}_{\mathrm{x}}$ concentration [12]. The use of additives can reduce $\mathrm{NO}_{\mathrm{x}}$ emissions margin-ally. It is therefore necessary to use the techniques like EGR to reduce $\mathrm{NO}_{\mathrm{x}}$ significantly especially when biodiesel is used as a fuel. Jatropha biodiesel (JBD) produces higher $\mathrm{NO}_{\mathrm{x}}$ in diesel engines when compared to other biodiesel fuels due to its lower cetane number as shown in Table 1. JBD combined with EGR operation in diesel engines reduces $\mathrm{NO}_{\mathrm{x}}$ emissions considerably [13]. Sunflower methyl ester biodiesel blend B20 combined with EGR 15\% produces $25 \%$ less $\mathrm{NO}_{x}$ compared to diesel fuel with increase in brake thermal efficiency (BTE) and brake specific fuel consumption (BSFC) [14]. EGR, when combined with proper injection timing and injection pressure can reduce the $\mathrm{NO}_{\mathrm{x}}$ emissions with a tradeoff on smoke and efficiency [15]. Emission standards like EURO-V necessitate higher EGR levels in diesel engines for cleaner emissions [16]. However, higher EGR levels are responsible for the development of gaseous emissions like hydrocarbons and for increased particle density and size in the exhaust. An optimum cold EGR of $10 \%$ can reduce BSFC and $\mathrm{NO}_{\mathrm{x}}$ considerably with reduction in soot emission when compared to the baseline engine [17]. The objective of this study is to investigate performance and emission characteristics of diesel engine fuelled with diesel-biodiesel blends with cetane improver Isobutanol as an additive in combination with exhaust gas recirculation.

\section{Experimental set-up and Procedure}

\subsection{Experimental Set-Up}

The experimental set-up is illustrated in Figure 1, which is a computerized single cylinder four stroke, naturally aspirated direct injection and air cooled diesel engine. The specifications of the test engine are given in Table 2. The engine is loaded with an eddy current dynamometer. An AVL five gas analyzer is used for measuring the CO, UHC, $\mathrm{NO}_{\mathrm{x}}, \mathrm{CO}_{2}$ and an AVL smoke meter is used for measuring the smoke opacity. For circulation of exhaust gases into the intake manifold, an EGR set-up was provided which consists of a control valve and a manometer. This engine is used for evaluation of performance, combustion and emission characteristics of biodiesel and diesel blends.

Table: Properties of the Oils

\begin{tabular}{|l|c|c|}
\hline \multicolumn{1}{|c|}{ Properties } & Diesel & Jatropha Oil \\
\hline Density $\left(\right.$ at $\left.30^{\circ} \mathrm{C}\right) /\left(\mathrm{g} \$ \mathrm{~mL}^{-1}\right)$ & $0.833-0.849$ & 0.9412 \\
\hline Kinematic viscosity $\left(\right.$ at $\left.30^{\circ} \mathrm{C}\right) / \mathrm{cSt}$ & $4-8$ & 51.56 \\
\hline Cetane No & $41-56$ & 37.80 \\
\hline Flash point $/{ }^{\circ} \mathrm{C}$ & $46-61$ & 211.00 \\
\hline Calorific value $/\left(\mathrm{MJ} \$ \mathrm{~kg}^{-1}\right)$ & $43-47$ & 38.90 \\
\hline
\end{tabular}




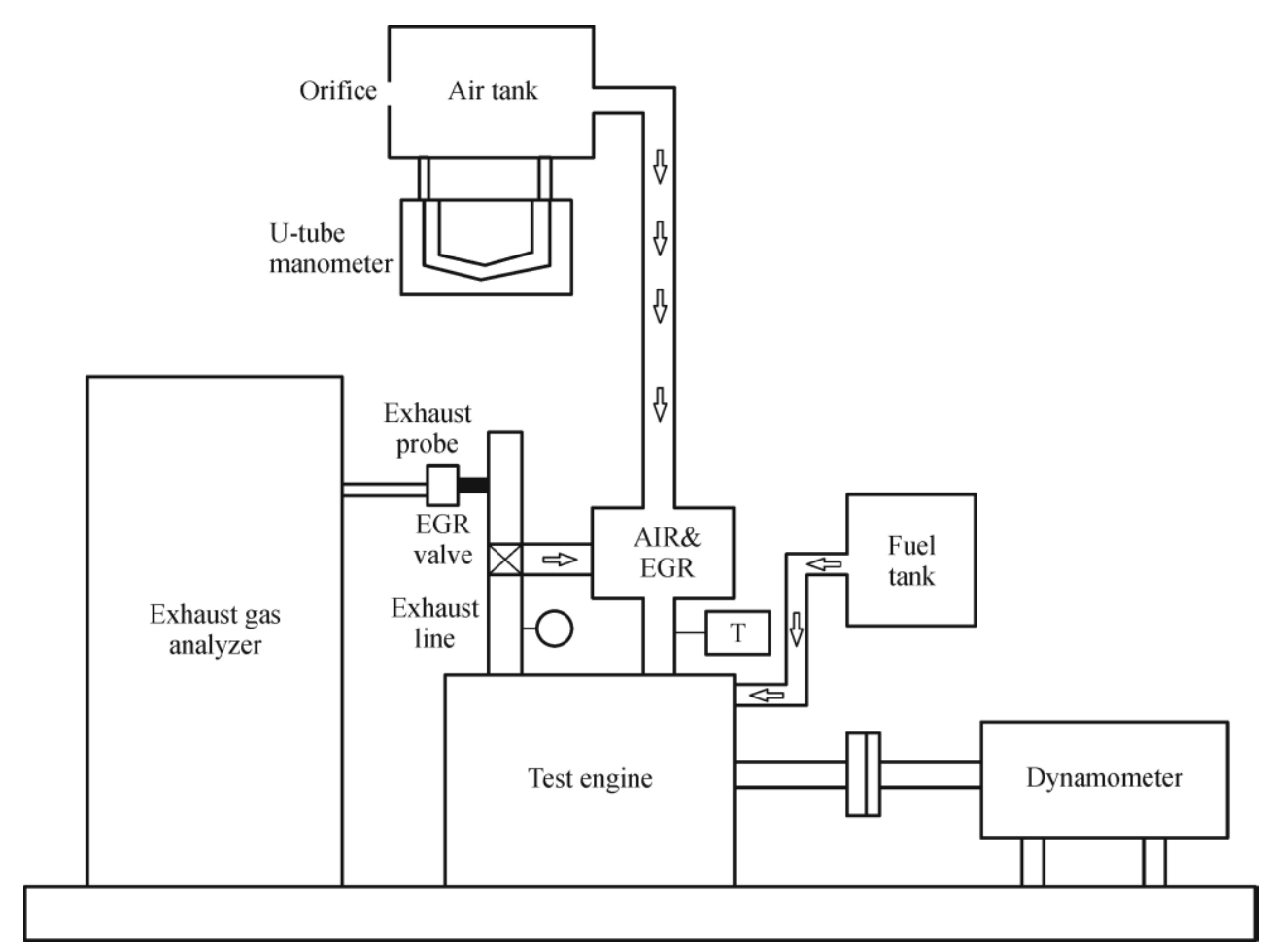

Figure 1. Test Engine

Table. Specifications of the Test Engine

\begin{tabular}{|l|c|}
\hline Particulars & Specifications \\
\hline Make & Kirloskar \\
\hline Rated power/Kw & 4.4 \\
\hline Bore/mm & 87.5 \\
\hline Stroke length/mm & 110 \\
\hline Swept volume/L & 0.661 \\
\hline Compression ratio & $17.5: 1$ \\
\hline Rated speed/(r\$min & -1 \\
\hline Injector operating pressure/MPa & 1500 \\
\hline Connecting rod length/mm & 21 \\
\hline Start of injection $(\mathrm{bTDC}) /\left({ }^{\circ}\right)$ & 220 \\
\hline
\end{tabular}

\subsection{Experimental Procedure}

The engine is operated at a constant speed of $1500 \mathrm{r} / \mathrm{min}$ with an injection advance of $24.9^{\circ}$. The first stage of experiment is performed with pure diesel at different loads from no-load to full load with EGR rates such as $0 \%, 10 \%$ and $20 \%$ at constant speed. The engine loads are adjusted by using an eddy current dynamometer. The exhaust gases are tapped from the exhaust pipe and connected to the inlet airflow passage. The rate of EGR is varied with the help of an EGR control valve which is fixed in the pipe control. The second stage of the experiment is conducted using various blends of diesel-biodiesel with cetane improver Isobutanol 1\% by volume (designated as B20E1, B30E1 and B40E1). 

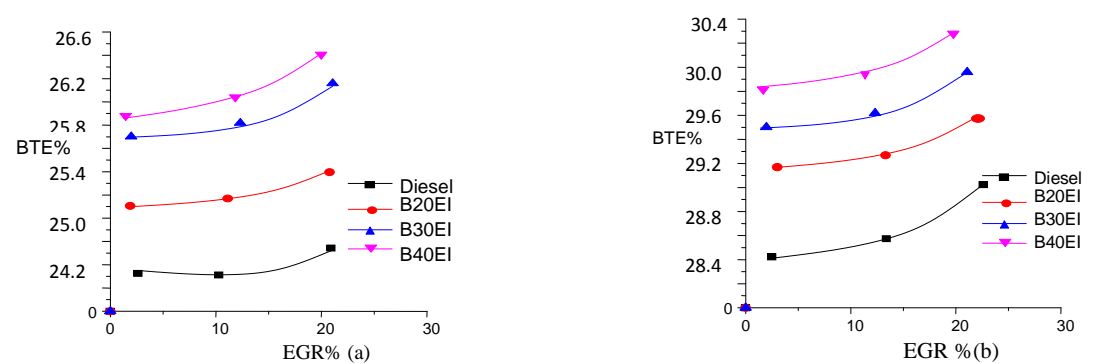

\section{Figure 2. Effect of Exhaust Gas Recirculation on BTE (a) $50 \%$ Load; (b) $100 \%$ Load}

\section{Results and Discussion}

\subsection{Performance Analysis}

The results obtained from the experimental investigation using diesel and different blends of biodiesel fuel with Isobutene as cetane improver with a variation in percentage mass fraction of EGR are presented in graphical form. Figures 2(a) and 2(b) illustrates the variation of BTE at different EGR by varying the percentage of biodiesel under $50 \%$ and $100 \%$ load. It is found that the brake thermal efficiency increases with EGR. The BTE is also found to be increasing with the increase in biodiesel at a fixed EGR percentage and there is an increase in the rate of BTE at 50\% load when compared to full load. This is due to the fact that at full load oxygen deficient operation under EGR is responsible for marginal increase in BTE. The increase in BTE with the increase in the percentage of EGR is due to the increased combustion velocity, as EGR increases the intake charge temperature. Figures 3(a) and 3(b) demonstrates the variation of BSFC with EGR by varying the percentage of biodiesel under $50 \%$ and $100 \%$ load. It is found that BSFC decreases considerably with the increase in EGR up to approximately 10\% EGR and this variation is found less at higher percentage of EGR. However, with the increase in biodiesel, the percentage of BSFC increases. This is due to the fact that the biodiesel blends have less energy content than diesel which causes fuel consumption to increase. Figures 4(a) and 4(b) exhibits the variation of exhaust gas temperature with EGR mass fraction. It is found that with the increase in the percentage of EGR as well as biodiesel, the exhaust gas temperature reduces. This reflects an effective utilization of heat energy. The addition of cetane improvers reduces the ignition delay which is responsible for reduction of combustion temperatures.
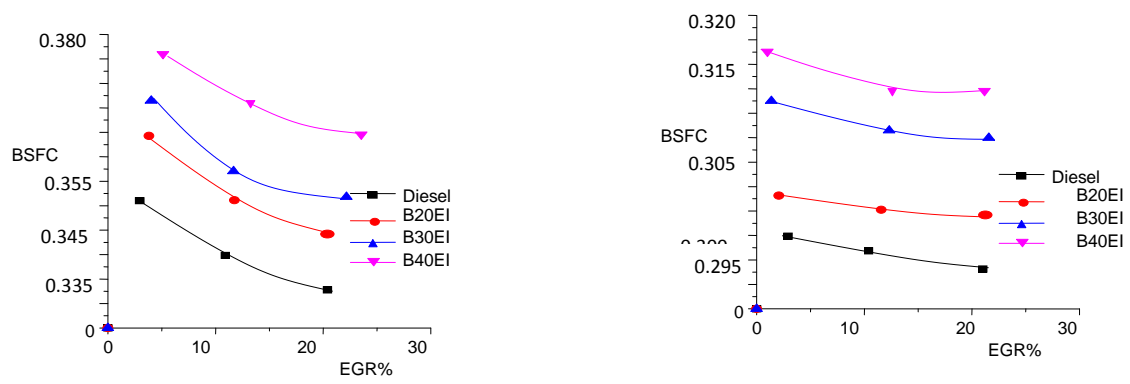

Figure 3. Effect of Exhaust Gas Recirculation on BSFC (a) $50 \%$ Load; (b) $100 \%$ Load 

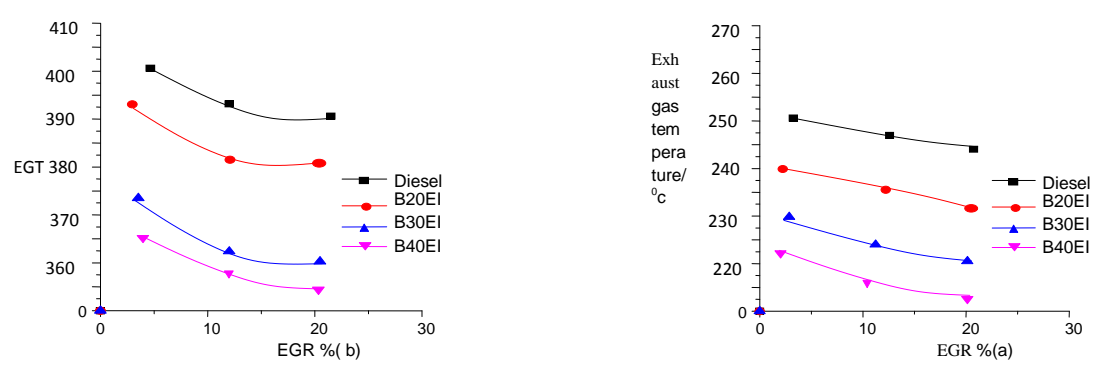

Figure 4. Effect of Exhaust Gas Recirculation on Exhaust Gas Temperature (a) $50 \%$ Load; (b) $100 \%$ Load

\subsection{Exhaust Emission Analysis}

Exhaust emissions such as $\mathrm{CO}, \mathrm{HC}, \mathrm{NO}_{\mathrm{x}}$, are measured with an AVL five gas analyzer while the smoke opacity is measured with an AVL smoke meter. Figures 5(a) and 5(b) displays the variation of $\mathrm{CO}$ emissions with the increase in the percentage of EGR at 50\% and $100 \%$ load. It is found that with the increase in EGR percentage, CO increases, while $\mathrm{CO}$ emission is found less at higher percentages of biodiesel. The deficiency of oxygen with the increase in EGR percentage can be attributed to the rapid growth of $\mathrm{CO}$ at the initial stages of EGR. However, the excess oxygen content in bio-diesel can compensate for the oxygen deficient operation under EGR as a result of which biodiesel maintains a lower CO than diesel at a fixed EGR. Figures 6(a) and 6(b) indicates that HC emissions increase considerably from $0 \%$ to $10 \%$ EGR for all fuels and beyond which there is a marginal increase. However, with the increase in biodiesel, $\mathrm{HC}$ emissions are found to decrease. Figures 7(a) and 7(b) shows that EGR and Isobutanol have a combined effect on reducing $\mathrm{NO}_{\mathrm{x}}$ emissions significantly. At 20\% EGR, biodiesel blend B40 with Isobutanol demonstrates greater reduction in $\mathrm{NO}_{\mathrm{x}}\left(110010^{-6}\right)$ against diesel without EGR $\left(162010^{-6}\right)$ which is $47 \%$ less. The reason for the greater reduction in $\mathrm{NO}_{\mathrm{x}}$ with combined EGR and Isobutanol is the reduction of combustion temperature as a result of the addition of exhaust gases to the intake air which increases the amount of combustion accompanying gases mainly $\mathrm{CO}_{2}$ which reduces the combustion temperature. Still higher EGR rates could Reduce $\mathrm{NO}_{\mathrm{x}}$ emissions by a large amount, which, however, is accompanied by a reduction in BTE and an increase in $\mathrm{CO}, \mathrm{HC}$ and smoke emissions. Figures $8(\mathrm{a})$ and 8 (b) shows that the increase in the smoke capacity is insignificant initially and continues with the further increase in EGR which also increases with the increase in the percentage of biodiesel.
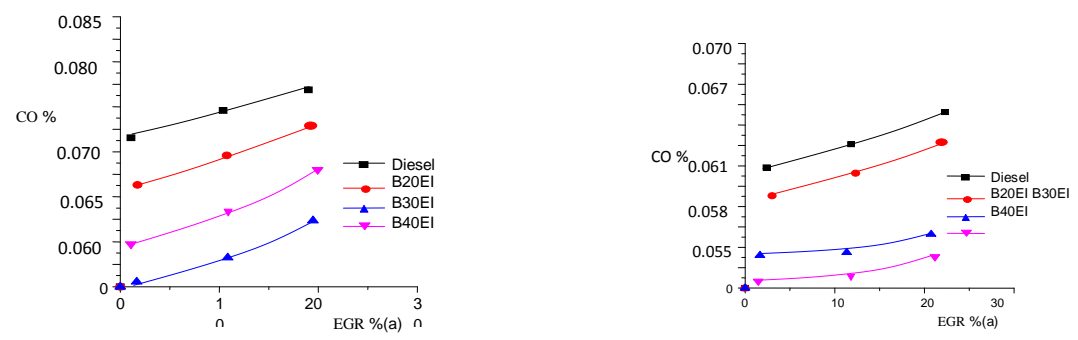

Figure 5. Effect of Exhaust Gas Recirculation on CO Emissions (a) $50 \%$ Load; (b) $100 \%$ Load 

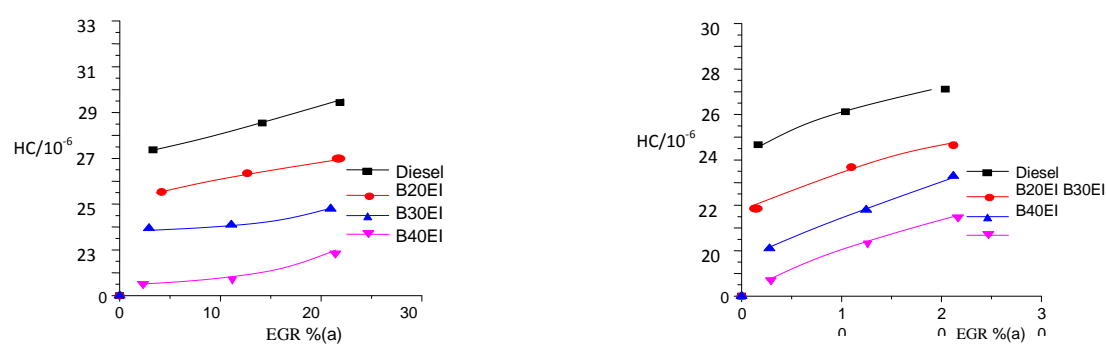

Figure 6. Effect of Exhaust Gas Recirculation on HC Emissions (a) $50 \%$ Load; (b) $100 \%$ Load
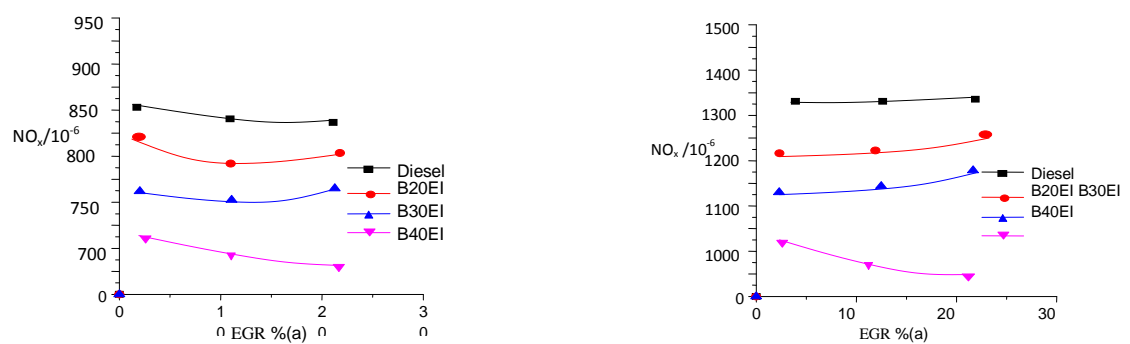

Figure 7. Effect of Exhaust Gas Recirculation on $\mathrm{NO}_{\mathrm{x}}$ Emissions (a) $50 \%$ Load; (b) $100 \%$ Load
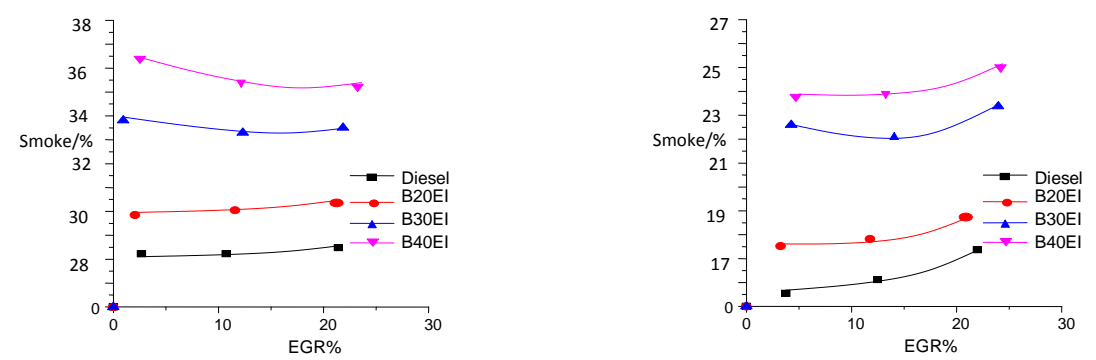

Figure 8. Effect of Exhaust Gas Recirculation on Smoke Opacity (a) $50 \%$ load; (b) $100 \%$ load

\section{Conclusions}

The conclusions drawn from the present experimental investigation are as follows:

1. With the increase in the percentage of EGR, BTE increases while BSFC and exhaust gas temperature decrease. The optimum EGR for the maximum BTE and the minimum BSFC is found to be $20 \%$.

2. $\mathrm{CO}$ and $\mathrm{HC}$ emissions are found to increase with the increase in the percentage of EGR. However at a fixed EGR, they are found to decrease with the increase in the percentage of biodiesel.

3. $\mathrm{NO}_{\mathrm{x}}$ decreases with the increase in the percentage of EGR, but at a fixed EGR, it decreases with the increase in the percentage of biodiesel.

4. The increase in smoke at $50 \%$ load is insignificant with the increase in the percentage of EGR while at full load it also increases considerably with the increase in the percentage of biodiesel. 
5. A higher percentage of EGR (20\%) can reduce $\mathrm{NO}_{\mathrm{x}}$ with the increase in BTE and other emissions for all the fuels. However the blends show fewer emissions than diesel at a fixed EGR percentage.

\section{References}

[1] N. Ladommatos, S. M. Adelhalim, H. Zhao and Z. Hu, "The effects of carbon dioxide in exhaust gas recirculation on diesel engine emissions", Proceedings of the Institution of Mechanical Engineers. Part D, Journal of Automobile Engineering, vol. 212, no. 1, (1998), pp. 25-42.

[2] S. Oberweis and T. Al-Shemmeri, "Effect of Biodiesel blending on emissions and efficiency in a stationary diesel engine", International Conference on Renewable Energies and Power Quality (ICREPQ'10), 2010, Granada, Spain, (2010).

[3] Y. X. Li, N. B. McLaughlin, B. S. Patterson and S. D. Burtt, "Fuel efficiency and exhaust emissions for biodiesel blends in an agricultural tractor", Canadian Bio-systems Engineering, vol. 48, (2006), pp. 215222.

[4] R. M. Alagu and E. G. Sundaram, "Nitrogen oxide emission in biodiesel fuelled CI engines-A review", Frontiers in Automobile and Mechanical Engineering, vol. 1, (2010), pp. 156-163.

[5] V. K. Belagur and V. R. Chitimini, "Effect of injector opening pressures on the performance, emission and combustion characteristics of DI diesel engine running on honne oil and diesel fuel blend", Thermal Science, vol. 14, no. 4, (2010), pp. 1051-1061.

[6] M. M. Roy, "Performance and emissions of a diesel engine fuelled by diesel-biodiesel blends with special attention to exhaust odor", Canadian Journal on Mechanical Sciences and Engineering, vol. 2, no. 1, (2011), pp. 1-10.

[7] N. Ladommatosa, S. Abdelhalima and H. Zhao, "Control of oxides of nitrogen from diesel engines using diluents while minimizing the impact on particulate pollutants", Applied Thermal Engineering, vol. 18, no. $11,(\mathbf{1 9 9 8})$, pp. $963-980$.

[8] X. G. Wang, B. Zheng, Z. H. Huang, N. Zhang, Y. J. Zhang and E. J. Hu, "Performance and emissions of a turbocharged, high-pressure common rail diesel engine operating on biodiesel/diesel blends", Proceedings of the Institution of Mechanical Engineers, Part D, Journal of Automobile Engineering, vol. 225, no. 1, (2010), pp. 127-139.

[9] G. D. Zhang, H. Liu, X. X. Xia, W. G. Zhang and J. H. Fang, "Effects of dimethyl carbonate fuel additive on diesel engine performances", Proceedings of the Institution of Mechanical Engineers, Part D, Journal of Automobile Engineering, vol. 219, no. 7, (2005), pp. 897-903.

[10] T. Nibin, A. P. Sathiyagnanam, S. Sivaprakasam and C. G. Saravanan, "Investigation on emission characteristics of a diesel engine using oxygenated fuel additive", I. E. Journal, (MC), vol. 86, (2005), pp. 51-54.

[11] N. Nabi and W. Chowdhury, "Improvement of engine performance using diethylene Glycol DI methyl ether (DGM) as additive", Jurnal Teknologi, vol. 44(A), (2006), pp. 1-12.

[12] N. Zhang, Z. H. Huang, X. G. Wang and B. Zheng, "A comparative study of two kinds of biodiesels and biodiesel-DEE blends in a common rail diesel engine", SAE International, Paper No. 2011-01-0640, (2011).

[13] M. Karabektas and M. Hosoz, "Performance and emission characteristics of a diesel engine using isobutanol-diesel fuel blends", Renewable Energy, vol. 34, no. 6, (2009), pp. 1554-1559.

[14] M. K. Nandi, "The performance of ditertiary-butyl peroxide as cetane improver in diesel fuels", Preprints of Papers-American Chemical Society, Division of Fuel Chemistry, vol. 41, no. 3, (1996), pp. 863-867.

[15] G. J. Suppes, K. Bockwinkel, M. H. Mason, J. B. Botts and J. A. Heppert, "Multifunctional diesel treatment additive from vegetable oils", BioEnergy'00. Buffalo, NY, (2000).

[16] S. Kobori, T. Kamimoto and A. Aradi, "A study of ignition delay of diesel fuel sprays", International Journal of Engine Research, vol. 1, no. 1, (2000), pp. 29-39. 
International Journal of Advanced Science and Technology Vol.92 (2016) 